\title{
URGENSITAS ULAMA DAN DAKWAH DALAM MEMBANGUN MASYARAKAT PERDESAAN
}

Oleh:

Drs. MUSTOPA, M. Ag.

Dosen Fakultas Ushuluddin Adab dan Dakwah (FUAD)

Institut Agama Islam Negeri (IAIN) Syekh Nurjati Cirebon Jawa Barat

\section{E-JURNAL EMPOWER ONLINE}




\title{
URGENSITAS ULAMA DAN DAKWAH \\ DALAM MEMBANGUN MASYARAKAT PERDESAAN \\ Oleh: \\ Drs. MUSTOPA, M. Ag. ${ }^{1}$ \\ tofaku66@gmail.com
}

\begin{abstract}
Abstrak
Manusia selalu berusaha untuk selalu bisa maju dan berkembang. Perkembangan kehidupan manusia yang lebih baik diantaranya ditandai dengan adanya pembangunan dalam berbagai aspek kehidupan, baik yang bersifat jasmani maupun rohani. Untuk menghindari kesalahan/ kerusakan dalam pembangunan yang dilakukan masyarakat tentu perlu adanya arahan dari orang-orang atau pihak-pihak yang memiliki kompetensi terkait dengan masalah tersebut. diantaranya adalah pemerintah dan ulama. Masyarakat, dalam upanya membangun perlu mendapatkan arahan dari pemerintah dan ulama. Hal ini mutlak perlu agar pembangunan yang dilakukannya tidak bertentangan dengan nilainilai budaya dan agama. Dengan adanya arahan dan masukan dari pemerintah dan ulama, tentunya pembangunan dapat terarah dan terkontrol dengan baik. Sehingga pembangunan tidak merusak lingkungan yang pada gilirannya justru akan menjadi sumber kehancuran bagi masyarakat itu sendiri.
\end{abstract}

Kata Kunci: Ulama, Dakwah, Pembangunan dan Masyarakat Perdesaan.

\section{Abstract}

Humans always try to always be able to move forward and develop. The development of human life is better marked by the presence of development in various aspects of life, both physical and spiritual. To avoid errors / damage in the development of the community would need the direction of the people or parties who have competence associated with the problem. Among them are government and ulama. The community, in its building, needs to get direction from the government and ulama. It is absolutely necessary that the development undertaken does not conflict with cultural and religious values. With the direction and input from the government and ulama, of course, development can be well directed and controlled. So that development does not damage the environment which in turn will be a source of destruction for society itself.

Keywords: Ulama, Da'wah, Development and Rural Community.

\footnotetext{
${ }^{1}$ Penulis adalah dosen Fakultas Ushuluddin Adab dan Dakwah (FUAD) Institut Agama Islam (IAIN) Syekh Nurjati Cirebon Jawa Barat.
} 


\section{B. ULAMA}

\section{Makna Ulama}

Seorang ulama merupakan pewaris Nabi, dalam artian ia mempunyai kewajiban untuk menjalankan ajaran-ajaran Nabi, ia pun memiliki tugas dan tanggung jawab untuk menyampaikan ajaran-ajaran tersebut kepada umat manusia.

Kewajiban untuk berdakwah ini sejalan dengan posisi yang disandangnya yakni sebagai pewaris Nabi. Posisi ini merupakan suatu posisi yang sangat terhormat. Namun tentu saja posisi tersebut harus dijaga karena hal tersebut merupakan amanah yang harus dijaga dan dilaksanakan dengan baik dan konsisten dalam memperjuangkannya

Uraian di atas menggambarkan betapa tidak sederhanya tugas dari ulama yakni menyampaikan pesanpesan keagamaan yang dulu disampaikan oleh Nabi kepada Umatnya.

Untuk mendapatkan pemahaman dan pengertian yang komprehensif kiranya perlu untuk mengetahui pengertian atau makna tentang ulama. Oleh karena itu penulis kemukakan beberapa pendapat para pakar tentang pengertian atau makna ulama, yang diantaranya adalah:

a. M. Quraish Shihab: Ulama ialah orang yang mempunyai pengetahuan tentang ayat-ayat Allah, baik yang bersifat kawniyyah maupun yang bersifat qur'aniyyah. ${ }^{2}$

b. Syekh Nawawi al-Bantani : "Ulama adalah orang-orang yang mcnguasai segala hukum syara' untuk menetapkan sahnya agama, baik penetapan sah i'tikad maupun amal

2 M. Quraish Shihab. Membumikan Al-Quran: Fungsi dan Peran Wahyu dalam Kehidupan Masyarakat. Bandung : Mizan. 1992., hlm 382

\section{A. PENDAHULUAN}

Manusia secara kodrati ingin memiliki kehidupan ekonomi yang baik dan mapan. Untuk bisa hidup mapan tentu dibutuhkan materi yang cukup. Untuk mendapatkan materi yang cukup diperlukan kemauan untuk usaha dan bekerja keras. Selain itu, manusia pun ingin memiliki tempat tinggal paling tidak yang representatif untuk berlindung dari terinya matari dan dari guyuran hujan.

Pada tingkat yang lebih tinggi, manusia ingin hidupnya makmur dan sejahtera, yang dimanifestasikan dengan tercukupinya sandang pangan dan papan. Untuk itu, dengan akal pikiran dan ilmu yang dimilikinya, manusia selalu berusaha untuk lebih maju dan terus maju, sehingga manusia mampu melakukan pembangunan di berbagai bidang.

Dalam upaua membangun tersebut, di situ masyarakat perlu mendapatkan arahan dari ulama -yang dengan dakwahnya-mengarahkan bagaimana pembangunan bisa dilakukan dengan baik dan benar, dalam artian tidak bertentangan dengan nilai-nilai ajaran agama. Sebagai contoh, membangun dengan tidak merusak lingkungan, atau membangun dengan tetap melestarikan dan menjaga alam. Dengan terjaganya alam maka kehidupan anak cucu generasi mendatang akan menjadi lebih nyaman dan sentosa karena alam dan lingkungan sekitar mereka masih benar-benar nyaman dan alami. Dengan demikian jelas bahwa membangun itu penting namun tak kalah pentingnya menjaga alam lingkungan. Denagn demikian harus membangun dengan tetap menjaga alam dan lingkungan sekitarnya. 
keridhaan Allah swt inilah ia pun akan berharap surga sebagai tempat kembalinya di alam baka kelak.

\section{DAKWAH}

\section{Makna Dakwah}

Dalam kehidupan sehari-hari sering menemukan istilah/kata dakwah. Karena itu, sesungguhnya istilah dakwah sudah bukan barang baru lagi bagi masyarakat. Namun demikian kiranya perlu juga untuk mengetahui definisi dakwah agar tidak terjadi salah paham tentang apa sesungguhnya yang dimaksud dengan dakwah.

Kata dakwah, secara etimologi, berasal dari bahasa Arab, (da'a, yad'u, da'watan), yang berarti seruan, panggilan, undangan, atau doa. ${ }^{4}$ Kata dakwah juga memiliki arti memanggil, menyeru, menegaskan, atau membela sesuatu, perbuatan, atau perkataan untuk menarik manusia kepada sesuatu serta memohon dan meminta ${ }^{5}$

Kata dakwah banyak ditemukan dalam kitab suci Al-Quran. Pentebutan kata dakwah dalam Al-Quran menjadi salah satu indikasi dari urgensitas dakwah. Diantara ayat-ayat dalam AlQuran yang menyinggung tentang masalah dakwah adalah:

Artinya: Allah menyeru (manusia) ke darussalam (surga), dan menunjuki orang yang dikehendakiNya kepada jalan yang lurus (Islam). .

4 Moch. Ali Aziz, Ilmu Dakwah. Jakarta : Prenada Media 2004., hlm., 2. Lihat juga. Ropingi el-Ishaq. Pengantar Ilmu Dakwah. Studi Komprehensif dari Teori ke Praktek. Malang : Madani., 2016., hlm., 6

5 A. Subandi dan Syukriadi Sambas, Epistemologi Dakwah. Bandung : KP Hadis. 1999 ., hlm., 17.

6 QS. Yunus 25. Arti kalimat darussalam ialah: tempat yang penuh kedamaian dan keselamatan. pimpinan (hidayah) Allah berupa akal dan wahyu untuk mencapai kebahagiaan dunia dan akhirat. syari'at Iainnya." Sedangkan Dr. Wahbah az-Zuhaili bcrkata, "Secara naluri, ulama adalah orang-orang yang mampu meng-analisa alam fenomena untuk kepentingan hidup dunia dan akhirat serta takut ancaman Allah jika terjerumus ke dalam kenistaan. Orang yang maksiat hakikatnya bukan ulama.".

c. Ibnu Katsir: "Ulama adalah yang benar-benar ma'rifatnya kepada Allah sehingga mereka takut kepada-Nya. Jika ma'rifatnya sudah sangat dalam maka sempurnalah takutnya kepada Allah."

d. Ali ash-Shabuni : "Ulama adalah orang yang rasa takumya kepada Allah sangat mendalam disebabkan ma'rifatnya."

e. Imam Mujahid : "Ulama adalah orang yang hanya takut kepada Allah SWT." Malik bin Anas pun menegaskan, "Orang yang tidak takut kepada Allah bukanlah ulama."

f. Hasan Basri : "Ulama adalah orang yang takut kepada Allah disebabkan perkara gaib, suka kepada setiap sesuatu yang disukai Allah, dan menolak segala sesuatu yang dimurkai-Nya."

g. Sayyid Quthub : "Ulama adalah orang yang senantiasa berpikir kritis akan Kitab Al-Qur'an (yang mendalam maknanya) sehingga mereka akan ma'rifat secara hakiki kepada Allah. Mereka ma'rifat.

Dari beberapa pengertian ulama di atas dapat dipahami bahwa ulama adalah orang yang takut kepada Allah dan menyebarkan Ilmu dari Allah kepada segenap ummat manusia dengan hanya mengharap keridhaan Allah SWT. Dan dengan mengharap

\footnotetext{
${ }^{3}$ Badruddin HSubky. Dilema Ulama dalam Perubahan Zxmqn Jakarta: Gema Insani Press. 1995., hlm., 45-46
} 
meningkatkan

kesejahteraan,

menyuburkan persamaan, dan mencapai kebahagiaan atas dasar ridla Allah SWT. ${ }^{11}$ Dengan demikian dakwah merupakan hal penting yang harus terus menerus dilakukan baik oleh individu maupun oleh kelompok.

Sedangkan secara terminologi, kata dakwah dapat didefinisikan sebagai ajakan kepada umat manusia menuju jalan Allah, baik secara lisan, tulisan, maupun perbuatan, dengan tujuan agar mereka mendapatkan petunjuk sehingga mampu merasakan kebahagiaan dalam hidupnya, baik di dunia maupun di akhirat.

Makna atau pengertian dakwah secara lengkap dapat ditemukan dari pendapat para ahli. Hal ini sebagaimana dihimpun oleh Aziz $(2004: 4-6):^{12}$

a. Menurut Supriadi Sambas (2004: 3), dakwah hakikatnya adalah perilaku keberagamaan Islam berupa internalisasi, transmisi, diftisi, dan trans-formasi ajaran Islam. Prosesnya melibatkan subjek \{dai), pesan \{maudlu), metode (uslub), media (washilah), dan objek (mad'u), yang berlangsung dalam rentang ruang serta waktu untuk mewujudkan kehidupan individu dan kelompok yang salam, hasanah, thayyibah serta memperoleh rida Allah Swt.

b. Menurut Syekh Ali Mahfudz, dalam kitabnya Hidayatul Mursyidin, dakwah adalah mendorong manusia untuk berbuat kebajikan dan mengikuti petunjuk (agama), menyeru mereka kepada kebaikan, serta mencegah dari perbuatan

${ }^{11}$ Enjang dan Aliyudin, 2009., hlm.,1 Dalam Enjang AS dan Hakir Tojiri., op., cit., hlm., 11

12 Moch. Ali Aziz, Ilmu Dakwah. Jakarta : Prenada Media, 2004., hlm., 4-6) Dalam Hajir Tajiri. Ibid., hlm.,16-17
Artinya: Yusuf berkata: "Wahai Tuhanku, penjara lebih Aku sukai daripada memenuhi ajakan mereka kepadaku. dan jika tidak Engkau hindarkan dari padaku tipu daya mereka, tentu Aku akan cenderung untuk (memenuhi keinginan mereka) dan tentulah Aku termasuk orangorang yang bodoh.". 7

Artinya :Dan apabila hambahamba-Ku bertanya kepadamu tentang aku, Maka (jawablah), bahwasanya Aku adalah dekat. Aku mengabulkan permohonan orang yang berdoa apabila ia memohon kepada-Ku, Maka hendaklah mereka itu memenuhi (segala perintah-Ku) dan hendaklah mereka beriman kepada-Ku, agar mereka selalu berada dalam kebenaran. ${ }^{8}$

Artinya: Dan jika kamu (tetap) dalam keraguan tentang Al Quran yang kami wahyukan kepada hamba kami (Muhammad), buatlah [, ${ }^{9}$ satu surat (saja) yang semisal Al Quran itu dan ajaklah penolong-penolongmu selain Allah, jika kamu orang-orang yang benar. ". 10

Dakwah pada dasarnya dapat dilakukan oleh siapapun sepanjang ia mau menyampaikan kebenaran. Oleh karena itu, dalam implementasinya, dakwah sesungguhnya merupakan kerja dan karya besar manusia -baik secara personal maupun sosial- yang dipersembahkan untuk Tuhan dan sesamanya adalah kerja sadar dalam rangka menegakkan keadilan,

${ }^{7}$ QS Yusuf 33

${ }^{8}$ QS. Al-Baqarah 186

${ }^{9}$ Ayat ini merupakan tantangan bagi mereka yang meragukan tentang kebenaran Al Quran itu tidak dapat ditiru walaupun dengan mengerahkan semua ahli sastera dan bahasa Karena ia merupakan mukjizat nabi Muhammad s.a.w.

${ }^{10}$ QS. Al-Baqarah 23) 
belenggu, kebekuan berpikir, kemiskinan, dan sifat malas, menyelamatkan manusia dari tindakan-tindakan kejahatan, tidak jujur, kejam, balas dendam, serta upaya membangun peradaban, mengantarkan manusia menjadi sosokyang mampu berkarya, berkreasi, dan berinovasi.

h. Menurut Muhyiddin (2002: 32-34), pengertian dakwah dijelaskan dengan fokus penekanan pada proses pemberian bantuan, penyebaran pesan, pengorganisasian, dan pemberdayaan sumber daya manusia. Sistem dalam menjelaskan kebenaran, kebaikan, petunjuk ajaran, menganalisis tantangan, problem kebatilan, urgensi pengamalan aspek pesan, dan profesionalisme. Pada intinya, dakwah merupakan perilaku muslim dalam menjalankan Islam sebagai agama dakwah.

i. H.S.M. Nasarudin Latif mendefinisikan dakwah sebagai usaha dengan lisan maupun tulisan yang bersifat menyeru, mengajak, memanggil manusia lainnya untuk beriman dan menaati Allah sesuai dengan garis-garis 'aqidah dan syariat serta akhlak Islam.

j. Secara sederhana kegiatan dakwah menurut pendapat Enjang dan Hajir Tajiri sesungguhnya merupakan proses mengajak manusia kepada alIslam yang dilakukan dengan' lisan atau tulisan (dakwah bi al-lisan dan bi al-qalani), juga bisa dengan perbuatan (dakwah bi al-hal) atau aksi sosial Islam (bi ahsan al-amal), dan mengorganisir serta mengelola kegiatan mengajak (bi al lisan, bi al-qalam, dan bi al-hal) dalam bentuk lembaga-lembaga Islam sebagai lembaga dakwah yang melakukan sistematisasi tindakan, mungkar agar memperoleh kebahagiaan di dunia dan akhirat.

c. Syekh Muhammad al-Ghazali, dalam bukunya Ma'a Allah, mengatakan bahwa dakwah adalah program pelengkap yang meliputi semua pengetahuan yang dibutuhkan manusia guna memberikan penjelasan tentang tujuan hidup serta menyingkap rambu-rambu kehidupan agar mereka menjadi orang yang dapat membedakan mana yang boleh dijalani dan mana kawasan yang dilarang.

d. Toha Yahya Oemar mengatakan, dakwah adalah mengajak manusia dengan cara bijaksana kepada jalan yang benar sesuai dengan perintah Tuhan untuk kemaslahatan dan kebahagiaan mereka di dunia dan akhirat.

e. Menurut Ilyas Ismail (2011: 37-38), makna general dakwah tersirat dari trilogi perjuangan Islam: khair, amar ma'ruf, dan nahi munkar. Dalam hal ini, dakwah berupaya untuk mengajak umat manusia menuju sistem moral yang berlandaskan ide al-ma'ruf sekaligus mengantisipasi kemungkinan terjerembab dalam al-munkar.

f. Menurut Aboebakar Atjeh, dalam bukunya Beberapa Catatan Mengenai Dakwah Islam, dakwah adalah seruan kepada seluruh manusia untuk kembali kepada ajaran hidup sesuai dengan ajaran yang benar. Dakwah mesti dilakukan dengan penuh kebijaksanaan dan nasihat yang baik.

g. Andy Dermawan dick. (2002: 27-37) berpendapat, dakwah dapat dijelaskan sebagai kegiatan mengkomunikasikan ajaran Islam, menyebarkan rahmat, menjadikan hidup manusia menjadi lebih baik, membebaskan diri manusia dari 
istilah: development, growth and change, modernization, atau bahkan juga progress. ${ }^{15}$ Karena itu, kian menjadi sangat sulit untuk mendefinisikan "pembangunan" dalam suatu rumusan yang dapat digunakan untuk memenuhi kebutuhan-kebutuhan, harapan-harapan, atau fungsi yang sangat beragam yang melekat pada istilah "pembangunan" itu. Sebab, pembangunan mencakup banyak makna, baik fisik maupun non-fisik, baik proses maupun tujuannya, baik yang duniawi maupun rohaniah. Pada istilah pembangunan melekat pula pengertian-pengertian: ekonomi, politik, maupun sosial dan kebudayaan.

Meskipun demikian, apapun maksud, tujuan, dan makna yang terkandung dalam pengertian yang dimaksudkan dalam satu istilah yang sama yaitu "pembangunan", kesemuanya akan selalu merujuk pada sesuatu yang mcmiliki arah positif, lebih baik dan lebih bermanfaat bagi kehidupan umat manusia secara individual maupun bagi masyarakatnya. ${ }^{16}$

Mengenai definisi tentang istilah pembangunan itu sendiri, Riyadi, sebagaimana dikutip oleh Aprillia Theresia , dkk ${ }^{17}$ mengungkapkan adanya beragam rumusan yang dikemukakan oleh banyak pihak, namun kesemuanya itu mengarah kepada ke suatu kesepakatan bahwa:

"Pembangunan adalah suatu usaha aiau proses perubahan, demi

15 (Raharjo, 1980). Dalam Totok Hardi Kanto dan Poerwoko Soebiato. Pemberdayaan Masyarakat dalam Prespektif Kebijakan Publik, Bandung : Alfabeta. 2013.

${ }^{16}$ (Hadad, 1980). Dalam Totok Hardi Kanto dan Poerwoko Soebiato. Ibid

17 Riyadi (1981) Dalam Aprillia

Theresia, dkk, Pembangunan Berbasis Masyarakat. Bandung : Alphabeta. 2014. kordinasi, sinkronisasi, dan integrasi program kegiatan dengan sumber daya dan waktu yang tersedia untuk mencapai sasaran dan tujuan dakwah Islam. Secara sederhana kegiatan ini dapat dilakukan dengan lisan (bi ahsan al- qawl) dan perbuatan (bi ahsan al-amal). ${ }^{13}$

Kegiatan dakwah tentu saja tidak hanya terpaku pada cerama, tapi kegiatan dakwah bisa dilakukan dengan berbagai cara yang kita bisa lakukan. Yang terpenting dakwah harus selalu dilakukan karena dakwah (menyampaikan kebenaran) adalah perlu dan harus disampaikan walaupun kebenaran itu terasa pahit atau menyakitkan.

\section{PEMBANGUNAN}

\section{Pengertian Pembangunan.}

Upaya-upaya untuk tercapainya kenaikan kesejahteraan hidup bagi setiap individu maupun masyarakat luas, dalam pengertian sehari-hari seringkali disebut sebagai upaya "pembangunan". ${ }^{14}$

Pendek kata, pembangunan merupakan segala upaya yang terusmenerus ditujukan untuk memperbaiki kehidupan masyarakat dan bangsa yang belum baik, atau untuk memperbaiki kehidupan yang sudah baik menjadi lebih baik lagi.

Istilah "pembangunan" yang biasa digunakan dalam bahasa Indonesia, dewasa ini telah semakin berkembang sebagai terjemahan dari beragam istilah asing, sehingga terkadang mengandung kerancuan pengertian. Pembangunan, dalam kehidupan sehari-hari, dapat digunakan sebagai terjemahan atau padanan

Ibid.,11-12

13 Enjang AS dan Hakir Tojiri.

14 Aprillia Theresia, dkk,
Pembangunan Berbasis Masyarakat.
Bandung: Alphabeta. 2014., hlm., 1


terus menerus mengalami perubahan-perubahan. Meskipun demikian, di dalam praktik, perencanaan pembangunan senantiasa memiliki batas waktu yang tegas, tetapi batasan-batasan itu pada hakikatnya hanyalah merupakan tahapan-tahapan yang harus dilakukan untuk menghadapi kondisi yang terjadi pada selang waktu yang sama, untuk kemudian terus dilanjutkan dengan tahapantahapan berikutnya yang juga dimaksudkan untuk terus memperbaiki mutu-hidup masyarakat (dan individu-individu di dalamnya) dalam suasana perubahan lingkungan yang akan terjadi pada selang waktu tertentu. PBM. Di Indonesia, selama pemerintahan Presiden Soeharto (1966-1990 tahapan-tahapan tersebut dibagi dalam jangka panjang (25 tahun) yang masingmasing terbagi dalam lima kali jangka menengah (5 tahun).

b. Proses pembangunan yang terjadi, bukanlah sesuatu yang sifatnya alami atau "given", melainkan suatu proses yang dilaksanakan dengan sadar dan terencana. Artinya, pembangunan tersebut dilaksanakan melalui suatu proses perencanaan terlebih dahulu, untuk menganalisis masalah-masalah atau kebutuhankebutuhan yang (akan) harus dipenuhi, tujuan-tujuan yang ditetapkan atau yang hendak dicapai, alternatif pencapaian tujuan dan pengambilan keputusan tentang cara-cara mencapai tujuan yang terpilih, dengan senantiasa mempertimbangkan: kekuatan, kelemahan, peluang, dan risiko yang harus dihadapi.

c Proses perubahan yang akan dilaksanakan dan ingin dicapai dalam setiap pembangunan, adalah tercapainya tingkat kesejahteraan, ${ }^{18}$ atau mutu-hidup suatu masyarakat (dan imiividu-individu di dalamnya) yang berkehendak dan melaksana-kan pembangunan itu."

\section{Pokok-Pokok Pikiran dalam Pembangunan.}

Pada dasarnya, di dalam istilah pembangunan, terkandung begitu banyak pokok-pokok pikiran, yang antara lain adalah sebagai berikut:

a. Pembangunan adalah suatu proses atau rangkaian kegiatan yang tidak pernah kenal berhenti, untuk terus menerus mewujudkan perubahanperubahan dalam kehidupan masyarakat dalam rangka mencapai perbaikan mutu-hidup, dalam situasi lingkungan kehidupan yang juga

$$
1 8 \longdiv { \text { Yang dimaksud dengan } }
$$

kesejahteraan di sini, bukanlah sekadar terpenuhinya "kebutuhan pokok" yang terdiri dari pangan, sandang, dan perumahan atau pemukiman, tetapi Goulet (Todaro, 1981) mengemukakan sedikitnya tiga nilai-nilai yang terkandung di dalamnya, yaitu: a. Tercapainya suasembada, dalam arti kemampuan masyarakat yang bersangkutan untuk memenuhi dan mencukupi kebutuhankebutuhan dasar yang mencakup: pangan, sandang, perumahan/ pemukiman, kesehatan, pendidikan-dasar, keamanan, rekreasi, dll. Peningkatan harga diri, dalam arti berkembangnya rasa percaya diri untuk hidup mandiri yang tidak tergantung kepada atau ditentukan oleh pihak lain, terlepas dari penindasan fisik maupun ideologi, dan tidak dimanfaatkan oleh pihak lain untuk kepentingan mereka. b. Diperolehnya suasana kebebasan, dalam arti adanya kesempatan dan kemampuan untuk mengembangkan dan untuk memilih alternatif-alternatif yang dapat dan boleh dilakukan untuk mewujudkan perbaikan mutu-hidup atau kesejahteraan yang terusmenerus bagi setiap individu sebagai warga masyarakat yang sedang membangun itu, tanpa adanya rasa takut dan tekanan dari pihak pihak lain. Aprillia Theresia, dkk, Pembangunan Berbasis Masyarakat., op., cit., hlm., 2 
yang dapat dilaksanakan" demi perbaikan mutu hidup masyarakat dan keluarganya.

e. Pembangunan adalah sesuatu yang: dari, oleh, dan untuk masyarakat. Sehingga, pembangunan bukanlah kegiatan yang direncanakan, dan dilaksanakan serta dimaksudkan untuk memenuhi kepentingan segolongan atau sekelompok warga masyarakat. Pembangunan mensyaratkan pelibatan atau "partisipasi seluruh warga masyarakat", sejak pengambilan keputusan tentang perencanaan pembangunan, sampai pada pelaksanaan dan pengawasan kegiatan, serta pemanfaatan hasilhasilnya oleh masyarakat. Pembangunan, bukanlah kegiatan yang dilaksanakan oleh pihak pemerintah untuk masvarakalnya, tetapi kegiatan yang dilaksanakan pemerintah. Dalam pengertian "pemerintah" maupun "masyarakat", termasuk di dalamnya adalah para tenaga-tenaga penyuluh atau "change agent" yang dapat berupa aparat pemerintah, aktivis lembaga swadaya masyarakat, pekerja sosial atau para inovator dan tokoh-tokoh (informal) masyarakat.

f. Pembangunan adalah pembangunan manusia seutuhnya dan pembangunan masyarakat yang bersangkutan. Artinya, pembangunan harus benar-benar dimaksudkan untuk memperbaiki mutu hidup setiap individu dan masya-rakatnya, dan bukannya mengorbankan manusia (dan masyarakatnya) demi tercapainya tujuan-tujuan pembangunan. ${ }^{19}$

$19 \overline{\text { Aprillia Theresia, dkk, }}$ Pembangunan Berbasis Masyarakat. Ibid., hlm., hlm., 3-4 perubahan yang menyeluruh yang menoakup beragam aspek dan lalanan kehidupan masyarakat yang bersangkulan. Pembangunan pada hakikatnya adalah suatu "eco development" yang tidak hanya berupa perubahan-perubahan ekonomi. Pembangunan juga mencakup "dehumanisasi" kultural dan penibahan mentalitas masyarakat dalam suatu struktur sosial-politik tertentu. Dengan demikian, pembangunan bukanlah sematamata bersifat ekonomi yang berupa kenaikan pendapatan, pertumbuhan dan pemerataan serta hal-hal lain yang dapat diukur dengan indikatorindikator ekonomi, melainkan mencakup banyak aspek nonmateriil seperti: penentuan nasib sendiri, swadaya, kemerdekaan, dan pengayoman politik, partisipasi, identitas kultural, kepribadian nasional, dsb. Berkaitan dengan itu, esensi setiap kegiatan pembangunan adalah terjadinya perubahan sikap untuk memproyeksikan diri ke dalam situasi lain dan karena itu secara sadar dan terencana menyiapkan diri untuk melakukan perubahan-perubahan untuk memperbaiki mutu-hidupnya guna mengantisipasi keadaan dan perubahan-perubahan yang akan terjadi di masa mendatang.

d. Pembangunan, dimaksudkan untuk menghasilkan individu-individu yang senantiasa memiliki kepekaan tentang: keadaan-keadaan yang akan terjadi, masalah-masalah yang sedang dan akan terjadi, alternatifalternatif yang mungkin dilaksanakan untuk mengatasi atau memecahkan masalah tersebut, dan dengan kemampuan sendiri (swakarsa, swadaya, swadana) mengambil keputusan untuk memilih alternatif-alternatif "terbaik 
oleh pelaku-pelaku pembangunan tersebut.

Terkait dengan persoalan pembangunan, Goulet (Todaro, 1981) sebagaimana dikutip oleh mengemukakan adanya tiga inti nilainilai yang terkandung dalam pengertian pembangunan, yaitu:

a. Swa-sembada, dalam artian kemampuan masyarakat dalam memenuhi atau mencukupi kebutuhan-kebutuhan dasar yang mencakup: sandang, pangan, perumahan, kesehatan, pendidikan dasar, dan keamanan.

b. Harga diri, dalam artian kepercayaan diri untuk tidak dimanfaatkan oleh pihak lain untuk kepentingan mereka atau hidup dalam penindasan.

c. Kebebasan, dalam artian kemampuan untuk memilih alternatif-alternatif bagi perbaikan mutu hidup atau kesejahteraan masyarakatnya. Karena itu, kesejahteraan yang dimaksud bukanlah dalam arti sekedar ekonomi (pendapatan) bagi tercukupinya sandang, pangan, dan papan, tetapi mencukupi kebutuhankebutuhan ekonomi, sosial, fisik, maupun mental dan spiritual, yang secara sederhana dapat dirumuskan (UPKM-YAKKUM，1997) sebagai berikut:

a. Enak makan, dalam arti tersedianya cukup pangan.

b. Enak tidur, dalam arti tidak mcmiliki beban psikologis.

c. Enak jalan-jalan, dalam arti sehat secara fisik.

d. Enak berpartisipasi, dalam arti memperoleh pengakuan sosial di
Adapun pengertian pembangunan menurut pendapat Mardikanto, adalah sebagai berikut:

Pembangunan adalah upaya yang dilakukan secara sadar dan terencana, dilaksanakan terus-menerus oleh pemerintah bersama-sama segenap warga masyarakatnya atau dilaksanakan oleh masyarakat dengan difasilitasi oleh pemerintah, dengan menggunakan teknologi yang terpilih, untuk memenuhi segala kebutuhan atau memecahkan masalah-masalah yang sedang dan akan dihadapi, demi tercapainya mutu-hidup atau kesejahteraan seluruh warga masyarakat dan snatu bangsa yang merencanakan dan melaksanakan pembangunan tersebut. $^{20}$

Pengertian tentang "pembangunan" sebagaimana telah dikemukakan dalam rumusan di atas, memberikan arahan bahwa:

a. Pembangunan, merupakan proses yang dilakukan oleh banyak pihak, dalam upayanya untuk terusmenerus memperbaiki mutu-hidup masyarakat dan individu-individu yang menjadi anggotanya.

b. Dalam rangka mencapai tujuan yang dikchendaki itu, kegiatan pembangunan senantiasa memanfaatkan teknologi yang terpilih, yang diyakini paling "baik" dalam arti berhasil guna (mangkus) dan berdaya-guna (sangkil).

c. Di dalam pengertian tujuan pembangunan untuk memperbaiki mutu-hidup masyarakat dan individu yang menjadi anggotanya tersebut, terkandung pemahaman tentang: upaya pemenuhan kebutuhan dan atau pemecahan masalah yang akan dihadapi atau yang telah dirasakan

\footnotetext{
${ }^{20}$ Mardikanto. T. Sistem Penyuluhan Pertanian. Surakarta: UNS Press. 2009
} 
menyatakan bahwa pembangunan terjadi karena terjadinya perubahan masyarakat tradisional ke arah masyarakat perkotaan.

3. Teori Struktural Fungsional. Parsons (1851) mengemukakan bahwa pembangunan terjadi karena adanya perubahan status dari suatu interaksi sosial yang terjadi dalam:

a. Adaptasi terhadap kebutuhan situasional.

b. Pencapaian tujuan-tujuan.

c. Integrasi atau pengaturan tatahubungan.

d. Pola pemeliharaan atau pengurangan ketegangan dari pola budaya tertentu.

4. Teori Ekonomi. Gunar Mrdal (1970) mengemukakan bahwa pembangunan terjadi karena beberapa kondisi ekonomi yang mencakup: a. hasil dan pendapatan, b. tingkat produktivitas, c. tingkat kehidupan, d. sikap dan pranata, e. rasionalitas.

5. Teori Konflik yang dicetuskan oleh Karl Marx (1919-1883) yang menyatakan bahwa pembangunan terjadi karena adanya konflik atau pertentangan kepentingan ekonomi antar kelas antara kelas pemodal (yang berkuasa) dan kelas yang tertindas (buruh).

6. Teori Ekologi, yang dikemukakan oleh Odum (1971) tentang hubungan antar manusia dengan lingkungannya (fisik dan sosial). Menurutnya, pembangunan terjadi sebagai akibat pemanfaatan sumberdaya alam yang melimpah, maupun optimasi pemanfaatan sumberdaya yang semakin terbatas.

$f$, Teori Ketergantungan yang berkembang di Amerika Latin sebagai-tnana dilaporkan oleh Frank (Wilber, 1979) di mana Negara maju mendominasi Negara yang tengah-tengah kehidupan masyarakatnya. . ${ }^{21}$

Kondisi seperti itu, ternyata menjadi dambaan setiap warga masyarakat, baik yang masih hidup secara subsisten atau bekerja untuk memenuhi kebutuhan hidupnya sendiri, keluarga dan masyarakatnya, maupun oleh masyarakat yang hidup dan bekerja secara rasional untuk selalu memperbaiki pendapatan dan kemanfaatannya dengan sebaikbaiknya sesuai dengan kebutuhan hidupnya.

Oleh sebab itu, setiap warga masyarakat dari suatu komunitas atau bangsa, selalu berupaya agar kehidupannya semakin bermutu dalam arti kehidupan yang semakin sejahtera. Sehingga dengan demikian mereka mampu berdiri sendiri dalam menjalani kehidupannya,

\section{Teori-Teori Pembangunan.}

Muhi et. al mengemukakan beberapa pendekatan teoritis tentang pembangunan, yaitu:

1. Teori Evolusi, yang mengacu kepada evolusi peradaban yang dikemukakan oleh Charles Darwin yang menyebutkan bahwa setiap komunitas akan mengalami perubahan dari kehidupan yang sangat sederhana kea rah yang semakin kompleks, sebagai akibat dari perubahan-perubahan: sosial, ekonomi, kependudukan, geografi, rasial, teknologi, maupun ideologi.

2. Teori Perubahan Sosial. Emile Durkheim (1964), yang menyatakan bahwa pembangunan terjadi sebagai akibat adanya perubahan struktur sosial dalam bentuk "pembagian pekerjaan". Sedang Redfield (1947)

$$
21 \overline{\text { Aprillia Theresia, dkk, }}
$$
Pembangunan Berbasis Masyarakat. ., op., cit., hlm., 8 . 
kegiatan, pemantauan, dan pengawasan, serta pemanfaatan hasil-hasil pembangunan. Dalam kenyataan, pelaksana utama kegiatan pembangunan justru terdiri dari kelompok ini; sedang kelompok "elit masyarakat" hanya berfungsi sebagai penerjemah "kebijakan dan perencanaan pembangunan" sekaligus mengorganisir dan menggerakkan partisipasi masyarakat. $^{23}$

Yang dimaksudkan dengan subsistem "pemerintah dan penggerak" adalah: semua aparat pemerintahan, penyuluh (change agent), pekerjasosial, tokoh-tokoh masyarakat (formal dan informal), aktivitas LSM/LPSM yang terlibat dan berkewajiban untuk:

1). Bersama-sama warga masyarakat merumuskan dan mengambil keputusan dan memberikan legitimasi tentang kebijakan dan perencanaan pem-bangunan.

2). Menginformasikan dan atau menerjemahkan kebijakan dan perencanaan pembangunan kepada seluruh warga masyarakat.

3). Mengorganisir dan menggerakkan partisipasi masyarakat.

4). Bersama-sama masyarakat melakukan pemantauan dan pengawasan ter-hadap pelaksanaan pembangunan.

5). Mengupayakan pemerataan hasilhasil pembangunan kepada seluruh warga masyarakat, khususnya yang terlibat langsung sebagai pelaksanaan dan atau dijadikan sasaran utama pembangunan secara adil.

Sedang yang dimaksudkan dengan sub-sistem masyarakat atau pengikut, adalah: sebagian besar warga masyarakat yang tidak termasuk dnliim

\footnotetext{
${ }^{23}$ Ibid., hlm., 8.
}

belum berkembang, sedemikian rupa Behingga pembangunan di Negara yang belum maju sangat tergantung kepada kehendak/kebutuhan Negara maju yang menjadi "penjajah"nya. ${ }^{22}$

\section{Pelaku-Pelaku Pembangunan.}

Rahim (Schramm dan Lerner, 1976) sebagaimana dikutp oleh Aprillia Theresia, dkk dalam bukunya yang berjudul pembangunan Berbasis Masyarakat mengungkapkan bahwa, di dalam setiap proses pembangunan, pada dasarnya terdapat dua kelompok atau "sub-sistem" pelaku-pelaku pembangunan, yang terdiri atas:

a. Sekelompok kecil warga masyarakat yang merumuskan perencanaan dan ber-kewajiban untuk mengorganisasi dan menggerakkan warga masyarakat yang lain untuk berpartisipasi dalam pembangunan. Pengertian merumuskan perencanaan pembangunan itu, tidak berarti bahwa ide-ide yang berkaitan dengan rumusan kegiatan dan cara mencapai tujuan hanya dilakukan sendiri oleh kelompok ini, akan tetapi mereka sekedar menimitskan semua ide-ide atau aspirasi yang dikehendaki oleh seluruh warga masvarakai melalui suatu mekanisme yang lolnh disepakati. Sedang perencanaan pembangunan di arus yang paling bawah, disalurkan melalui pertemuan kelompok atau permusyawaratan pada lembaga yang terbawah, secara formal maupun informal.

b. Masyarakat luas yang berpartisipasi dalam proses pembangunan, baik dalam bentuk: pemberian input (ide, biaya, tenaga, dll.), pelaksanaan

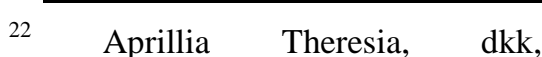
Pembangunan Berbasis Masyarakat. Bandung : Alphabeta. 2014., hlm., 12-13.
} 
masalah yang sedang dan akan dihadapi masyarakat. Untuk itu, terdapat tiga hal yang harus selalu diingat, yaitu:

a. Adanya keterlibatan anggota-anggota masyarakat untuk memberitahukan kepada penguasa tentang apa dan bagaimana dengan sebaik-baiknya pembangunan yang direncanakan harus mampu menolong mereka, dan sebaliknya, penguasa tidak boleh hanya percaya terhadap hasilhasil konsultasi antar jenjang birokrasi pemerintah.

b. Adanya hak "tawar-menawar" (bargaining power) yang dimiliki oleh sub-sistem pengikul (masyarakat). Artinya, masyarakat harus diberi kesempatan untuk bila perlu menolak kebijakan atau program-program dan proyek pembangunan yang tidak mencerminkan kebutuhan masyarakat atau kebutuhan masyarakat atau kegiatan pembangunan yang akan terlalu banyak menuntut pengorbanan masyarakat tanpa imbangan manfaat yang layak yang dapat dinikmati oleh masyarakat yang akan diwajibkan untuk memberikan pengorbanan tersebut.

c. Setiap perencanaan harus selalu merupakan "proses belajar" (learning process), yaitu perlunya ada keinginan para perumus kebijakan dan perencanaan pembangunan untuk belajar dari pengalaman masyarakat dan menggunakannya sebagai acuan sebelum pengambilan keputusan.

2. Masyarakat harus selalu diberitahu tentang apa yang sedang dan telah direncanakan oleh penguasa, serta diberitahu cara-cara yang telah dipilih untuk melaksanakan pembangunan yang direncanakan itu. Untuk selanjut-nya, masyarakat sub-sistem "pemerintah/penggerak" di atas, yang berkewajiban untuk:

I), Menyampaikan ide-ide atau gagasan tentang kegiatan pembangunan yang perlu dilaksanakan, dan cara mencapai tujuan pembangunan $\backslash$ .iii)', diharapkan, I'.iik sc(,u,i I,in)','.uii)', maupun melalui perwakilannya yang sah dalam suatu forum yang diselenggarakan untuk keperluan tersebut.

2). Secara positif menerima dan aktif berpartisipasi dalam pembangunan, sejak pengambilan keputusan tentang kebijakan dan perencanaan pembangunan, pelaksanaan kegiatan, pemantauan dan pengawasan, dan upaya pemerataan hasil-hasil pembangunan secara adil sesuai dengan fungsi dan pengorbanan yang telah diberikan.

3). Memberikan masukan atau umpan balik tentang kegiatan pembangunan yang telah dilaksanakan.

4. Menerima dan memanfaatkan hasilhasil pembangunan.

Sehubungan dengan itu, demi keberhasilan pembangunan kedua kelompok pelaku-pelaku pembangunan perlu menjalin hubungan psikologis yang akrab, sehingga dapat terjalin komunikasi atau berinteraksi secara efektif. Di samping itu, antar pelaku-pelaku pembangunan di dalam setiap kelompoknya masing-masing juga perlu melakukan hal yang sama.

Tentang hal ini, beberapa hal berikut ini perlu mendapat perhatian dari kedua sub-sistem pelaku-pelaku pembangunan:

1. Aparat pemerintah/penguasa, di dalam pengambilan keputusan tentang kebijakan dan perencanaan pembangunan harus senantiasa mau: men-dengarkan, memahami, dan menghayati aspirasi masyarakat, memahami kondisi dan masalah- 
kesatuan sosial yang mempunyai batasbatas tertentu. $^{27}$

Sedangkan masyarakat menurut

Murtadha Muthahhari adalah kelompok manusia yang saling terkait oleh sistem-sistem, adat istiadat, ritus-ritus dan hukum-hukum khas yang hidup bersama. $^{28}$

Berdasarkan uraian di atas dapat dipahami bahwa yang dimaksud dengan masyarakat adalah suatu kelompok manusia yang digunakan untuk menggambarkan ikatan atau interaksi antara pihak-pihak yang bersahabat. Dalam arti asosiasi, sebuah masyarakat adalah tubuh individu digariskan oleh batas-batas saling ketergantungan fungsional, terdiri dari karakteristik seperti identitas nasional atau budaya, solidaritas sosial, bahasa atau organisasi hierarkis. Lebih luasnya, masyarakat merupakan infrastruktur ekonomi, sosial, atau industri, terdiri dari kumpulan individu bervariasi.

\section{Pengertian Desa.}

Pengertian Desa menurut Undang-Undang No. 5 Tahun 1979 tentang Pemerintah Daerah Desa adalah suatu wilayah yang ditempati oleh sejumlah penduduk sebagai kesatuan masyarakat hukum, yang mempunyai organisasi pemerintahan terendah, langsung di bawah camat dan berhak menyelenggara-kan rumah tangganya sendiri dalam ikatan Negara Kesatuan Republik Indonesia. ${ }^{29}$

Sedangkan menurut Sutardjo Kartohadikusumo bahwa desa adalah

27 Sidi Gazalba, Masyarakat Islam., op., cit., hlm. 5.

${ }^{28}$ Murtadha Muthahhari, Masyarakat dan Sejarah, (Bandung: Mizan, 1993), hlm. 15.

29 Syamsuddin. AB. Pengantar Sosiologi Dakwah. Kencana Prenada Media Group. Jakarta: 2016., hlm., 224. harus aktif mempersiapkan diri untuk berpartisi-pasi di dalam proses pembangunan tersebut.

3. Masyarakat harus ditingkatkan kemampuannya (pengetahuan, sikap, ke-terampilan) dan diberi kesempatan seluas-luasnya untuk berpartisipasi dan di dalam setiap kegiatan pembangunan, sejak pengambilan keputusan perencanaan pembangunan hingga pemanfaatan hasil-hasil pembangunan yang terwujud dengan baik. ${ }^{24}$

\section{E. MASYARAKAT PERDESAAN}

\section{Pengertian Masyarakat}

Istilah masyarakat berasal dari bahasa Arab "syarikah" yang berarti perkumpulan. $^{25}$ Istilah masyarakat yang berasal dari kata syarikah terscbut lebih dikenal dan bcgitu familiar bagi masyarakat Indonesia diban-dingkan istilah Arab al-mujtama' yang berarti masyarakat.

Kata masyarakat menurut W.J.S. Poerwadarminta dalam Kamus Besar Bahasa Indonesia diartikan sebagai pergaulan hidup manusia (himpunan orang yang hidup bersama di suatu tempat dengan ikatan-ikatan aturan yang tentu). ${ }^{26}$

Ralph Linton yang dikutip oleh Sidi Gazalba, menjelaskan bahwa yang dimaksud dengan istilah masyarakat adalah kelompok manusia yang cukup lama hidup dan bekerja sama schingga dapat mengorganisasikan dirinya dan berpikir mengenai dirinya sebagai

24 Aprillia Theresia, dkk, Pembangunan Berbasis Masyarakat., i, hlm., 10-11.

25 Sidi Gazalba, Masyarakat Islam Pengantar Sosiologi dan Sosiografi, (|akarra: Bulan Bintang, 1976), hlm. 1

26 W.J.S. Poerwadarminta. Kamus Umum Bahasa Indonesia, Jakarta : Balai Pustaka 1991., hlm., 636 
cukup lama, yang mendiami suatu wilayah(lokalitas/tempatan), mandiri, memiliki kebudayaan yang sama, dan melakukan sebagian besar kegiatannya dalam kelompok tersebut dalam jumlah sekitar sampai 2.500 orang, dengan kelas sosial yang intim, pribadi, dan afeksi dari ekspresi kehendak alamiah (wessenwille) dengan ekonomi nonpasar. $^{32}$

\section{Ciri-Ciri Masyarakat Perdesaan}

Tallcot Parson menggambarkan masyarakat desa sebagai masyarakat tradisional (gemeinschaft) yang mengenal ciri-ciri, sebagai berikut:

a) Afektivitas ada hubungannya dengan perasaan kasih sa- \yang, cinta, kesetiaan, dan kemesraan. Perwujudannya dalam sikap dan perbuatan tolong-menolong, menyatakan simpati terhadap musibah yang diderita orang lain dan menolongnya tanpa pamrih.

b) Orientasi kolektif, sifat ini merupakan konsekuensi dari afektivitas, yaitu mereka mementingkan kebersamaan, tidak suka menonjolkan diri, tidak suka akan orang yang berbeda pendapat, intinya semua harus memperlihatkan keseragaman persamaan.

c) Partikularisme pada dasarnya adalah semua hal yang ada hubungannya dengan keberlakuan khusus untuk suatu tempat atau daerah tertentu. Perasaan subjektif, perasaan kebersamaan, sesungguhnya yang hanya berlaku untuk kelompok tertentu saja (lawannya universalisme).

d) Askripsi, berhubungan dengan mutu atau sifat khusus yang tidak diperoleh berdasarkan suatu usaha

32 Damsar dan Indrayani Pengantar Sosiologi Perdesaan. Jakarta : Kencana 2016., hlm., 74 suatu kesatuan hukum tempat tinggal suatu masyarakat berkuasa mengadakan pemerintahan sendiri. Desa merupakan perwujudan atau kesatuan geografis, sosial, ekonomi, politik, dan kulural yang terdapat di suatu daerah dalam hubungan dan pengaruhnya secara timbal balik dengan daerah lain. Warga suatu masyarakat perdesaan mempunyai hubungan yang Iebih erat dan lebih mendalam ketimbang hubungan mereka dengan warga masyarakat perdesaan lainnya. Dan Sistem kehidupan biasanya berkelompok atas dasar sistem kekeluargaan. ${ }^{30}$

Selanjutnya, Pudjiwati menjelaskan ciri-ciri relasi sosial yang ada di desa itu, adalah pertama-tama, hubungan kekerabatan. Sistem kekerabatan dan kelompok kekerabatan masih memegang peranan pen-ting. Penduduk masyarakat perdesaan pada umumnya hidup dari pertanian, walaupun terlihat adanya tukang kayu, tukang genteng dan bata, tukang membuat gula, akan tetapi inti pekerjaan penduduk adalah pertanian. Pekerjaan-pekerjaan di samping pertanian, hanya merupakan pekerjaan sambilan saja. ${ }^{31}$

2. Pengertian

Masyarakat Perdesaan.

Masyarakat pedesaan menurut pendapat Horton dan Hunt sebagaimana dikutip oleh Damsar dan Indrayani dalam bukunya yang berjudul pengantar Sosiologi Perdesaan. Jakarta : Kencana 2016 sekumpulan manusia yang relatif mandiri, yang hidup bersama-sama ,

$3 0 \longdiv { \text { Soekanto, Soerjono. Sosiologi } }$ Suatu Pengantar. Jakarta : RajaGrapindo. 1994.

31 Syamsuddin. AB. Pengantar Sosiologi Dakwah. ., op., cit., hlm., 224 
kepercayaan masyarakat sekitar yang membuat masyarakat perdesaan masih kaku, tetapi asalkan tidak melanggar hukum adat dan kepercayaan maka masyarakat perdesaan adalah masyarakat yang ramah. Pada hakikatnya, masyarakat perdesaan adalah masyarakat pendukung seperti sebagai petani yang menyiapkan bahan pangan, sebagai pekerjaan yang biasanya hanya bersifat pendukung tetapi terlepas dari itu masyarakat perdesaan banyak juga yang sudah berpikir maju dan keluar dari hakikat itu. Dengan demikain, masyarakat perdesaan memiliki perilaku dan sifat yaitu: perilaku homogeni, perilaku yang dilandasi oleh konsep kekeluargaan dan kebersamaan, perilaku yang berorientasi pada tradisi dan status, isolasi sosial, sehingga statik, kesaruan dan keutuhan kultural, banyak ritual dan nilai-nilai sakral, kolektivisme, sederhana, mudah curiga, menjunjung tinggi "unggah-ungguh" atau kesopanan, lugas (terturup dalam hal keuangan), perasaan "minder" terhadap orang kota, menghargai orang lain, jika diberi janji, akan selalu diingat, suka gotong royong, demokratis, dan religius. ${ }^{35}$

\section{Berbagai Jenis Gejala Masyarakat Perdesaan.}

Masyarakat perdesaan mengenal berbagai jenis gejala sosial, khususnya hal ini merupakan sebab-sebab bahwa di dalam masyarakat perdesaan penuh dengan ketegangan-ketegangan sosial. Gejala-gejala sosial, sebagai berikut:

a) Konflik (pertengkaran). Pertengkaran-pertengkaran yang terjadi biasanya berkisar pada masalah sehari-hari rumah tangga

35 Syamsuddin. AB. Pengantar Sosiologi Dakwah., op., cit., hlm., 226 yang tidak disengaja, tetapi merupakan suatu keadaan yang sudah merupakan kebiasaan atau keturunan (lawanya prestasi).

e) Kekabaran (diffuseness). Sesuatu yang tidak jelas terutama dalam hubungan antara pribadi tanpa ketegasan yang dinyatakan eksplisit. Masyarakat desa menggunakan bahasa tidak langsung, untuk menunjukkan sesuatu. ${ }^{33}$

Adapun menurut Poplin (1972) sebagaimana yang dikutip oleh bahwa masyarakat desa memiliki ciri-ciri, yaitu: perilaku homogeni, perilaku yang dilandasi oleh konsep kekeluargaan dan kebersaniaan, perilaku yang berorientasi pada tradisi dan status, isolasi sosial, sehingga statik, kesaruan dan keutuhan kultural, banyak ritual dan nilai-nilai sakral, dan kolektivisme. ${ }^{34}$

Dengan demikian, masyarakat perdesaan ditandai dengan pemilikan ikatan perasaan batin yang kuat sesama warga desa yaitu perasaan setiap anggota masyarakat yang sangat kuat yang hakikatnya yaitu di dalam masyarakat perdesaan di anta-ra warganya mempunyai hubungan yang lebih mondalam dan erat bila dibandingkan dengan masyarakat perdesaan lainnya di luar batas wilayahnya, sistem kehidupan umumnya berke-lompok dengan dasar kekeluargaan, dan sebagian besar warga masyarakat perdesaan hidup dari pertanian.

\section{Sifat dan Hakikat Masyarakat Perdesaan. \\ Masyarakat perdesaan} mempunyai sifat yang kaku tetapi sangatlah ramah dan biasanya adat dan

\footnotetext{
33 Syamsuddin. AB. Pengantar Sosiologi Dakwah., op., cit., hlm., 225

${ }^{34}$ Ibid., hlm., 226
} 
keberadaan dakwah pada dasarnya dibutuhkan oleh siapapun dalam semua lapisan masyarakat. Tak terkecuali masyarakat pedesaan. Masyarakat pedesaan yang masih bersifat sederhana tidak berarti bahwa mereka tidak ingin maju seperti masyarakat perkotaan. Namun untuk bisa maju tentu saja ada banyak hal yang diperlukan. diantaranya; pemikiran dan teologi yang ada pada mereka haruslah teologi yang bersifat rasional. Teologi yang bersifat rasional ini sangat mengedepankan akal pikiran. Dengan akal pikirannya, manusia bisa berpikir secara positif dan progresif, serta berkembang. Pemikiran yang progresif tentu bisa memahami arti dan hakekat hidup sebagai sebuah perjuangan dan ibadah.

Pemahaman hidup sebagai perjuangan bearti bahwa dalam hidup harus selalu berusaha dan berjuang untuk terus maju dan berkembang. Pemikiran yang demikian tentu saja tidak akan memaknai hidup sebagai sebuat takdir an sich tanpa harus mengesampingkan usaha dan ikhtiar untuk bisa maju dan berkembang dengan cara membangun, membangun dan membangun.

Adapun pemahaman hidup sebagai ibadah tentu akan berimplikasi bahwa apapun yang dikerjakannya dalam hidup ini harus bernilai ibadah kepada Allah swt. Dengan pemikiran yang demikian maka apapun yang diperbuatnya harus dengan niat ibadah dan dilakukan dengan sungguhsungguh dan sejalan denganan ajaran agama dan norma-norma susila. dan sering menjalar ke luar rumah tangga.

b) Kontraversi (pertentangan). Pertentangan ini bisa disebabkan oleh per-ubahan konsep-konsep kebudayaan (adat istiadat), psikologi atau dalam hubungannya dengan guna-guna (black magic). Para ahli hukum adat biasanya meninjau masalah kontroversi ini dari sudut kebiasaan masyarakat.

c) Kompetisi (persiapan). Masyarakat perdesaan adalah ma-nusia yang mem-punyai saingan dengan manusia lain, oleh karena itu maka wujud per-saingan bisa positif dan bisa negatif.

d) Kegiatan pada masyarakat perdesaan. Masyarakat perdesaan mempunyai penilaian yang tinggi terhadap mereka yang dapat bekerja keras tanpa bantuan orang lain.

Jadi, jelas masyarakat perdesaan bukanlah masyarakat yang senang diam-diam tanpa aktivitas, tanpa adanya suatu kegiatan tetapi kenyataannya adalah sebaliknya. Masyarakat perdesaan lebih beranggapan bahwa di kota lebih banyak pekerjaan dan lebih mudah mendapatkannya, karena inilah masyarakat perdesaan berbondongbondong datang ke Jbu-kota untuk mencari pekerjaan dan akibatnya malah banyak pengangguran di Ibukota, dan ini juga yang membuat Ibu-kota menjadi semakin macet dan berbahaya karena jumlah pengangguran semakin tinggi dan banyak orang yang ingin mendapatkan pekerjaan untuk kebutuhan hidup keluarganya. ${ }^{36}$

\section{F. PENUTUP}

Dakwah sesungguhnya tidak mengenal status ekonomi ataupun status sosial. Maksudnya, bahwa

${ }^{36}$ Ibid., hlm., 227 
Publik, Bandung: Alfabeta. 2013.

W.J.S. Poerwadarminta. Kamus Umum Bahasa Indonesia, Jakarta: Balai Pustaka 1991.

\section{DAFTAR BACAAN}

A. Subandi dan Syukriadi Sambas, Epistemologi Dakwah. Bandung: KP Hadis. 1999

Aprillia Theresia, dkk, Pembangunan Berbasis Masyarakat. Bandung: Alphabeta. 2014.

Badruddin HSubky. Dilema Ulama dalam Perubahan Zxmqn Jakarta: Gema Insani Press. 1995.

Damsar dan Indrayani Pengantar Sosiologi Perdesaan. Jakarta: Kencana 2016.

M. Quraish Shihab. Membumikan AlQuran: Fungsi dan Peran Wahyu dalam Kehidupan Masyarakat. Bandung : Mizan. 1992.

Mardikanto. T. Sistem Penyuluhan Pertanian. Surakarta: UNS Press. 2009

Moch. Ali Aziz, Ilmu Dakwah. Jakarta : Prenada Media 2004.

Murtadha Muthahhari, Masyarakat dan Sejarah, Bandung: Mizan, 1993.

Ropingi el-Ishaq. Pengantar Ilmu Dakwah. Studi Komprehensif dari Teori ke Praktek. Malang: Madani., 2016.

Sidi Gazalba, Masyarakat Islam Pengantar Sosiologi dan Sosiografi, (Jakarta: Bulan Bintang, 1976.

Soekanto, Soerjono. Sosiologi Suatu Pengantar. Jakarta: RajaGrapindo. 1994.

Syamsuddin. AB. Pengantar Sosiologi Dakwah. Kencana Prenada Media Group. Jakarta: 2016

Totok Hardi Kanto dan Poerwoko Soebiato. Pemberdayaan Masyarakat dalam Prespektif Kebijakan 